\title{
Bell Pepper (Capsicum annum L.) under Colored Shade Nets: Plant Growth and Physiological Responses
}

\author{
Juan Carlos Díaz-Pérez \\ Department of Horticulture, University of Georgia, 2360 Rainwater Road, \\ Tifton, GA 31793
}

Kelly St. John

Trellis Growing Systems LLC, 2427 S. Hadley Road, Fort Wayne, IN 46804

Additional index words. plasticulture, shade house, climate change, heat stress, photomorphogenesis

\begin{abstract}
Use of colored shade nets has shown benefits in bell pepper and other horticultural crops. There is still, however, limited information on plant growth and physiology of bell pepper crop grown under colored shade nets. The objective was to determine the effects of colored shade nets on plant growth, leaf gas exchange, and leaf pigments of field-grown bell pepper. Experimental design was a randomized complete block with four replications and five shade treatments (black, red, silver, and white nets, and an uncovered control). Mean and maximal air temperature and midday root zone temperature (RZT) were highest in the unshaded treatment. Differences in air temperatures between shade net treatments were smaller compared with the differences in RZT between treatments. Plant fresh weight and stem diameter were reduced in the unshaded treatment, and there were no plant fresh weight and stem diameter differences among shade nets. The incidence of Phytophthora blight (caused by Phytophthora capsici) was greatest in the unshaded treatment. Leaf stomatal conductance $\left(g_{s}\right)$ and photosystem II efficiency were reduced and leaf temperature increased in unshaded conditions. Leaf net photosynthesis, $g_{\mathrm{S}}$, internal $\mathrm{CO}_{2}$, and PSII efficiency decreased with increasing leaf temperature. Differences in leaf temperature among shade net treatments were because of differences in solar radiation captured by leaves. Leaf total carotenoids were lowest in unshaded conditions and there were no differences in total carotenoids among the shade nets. Chlorophyll $a$ concentration and chlorophyll $a / b$ ratio was lowest in unshaded conditions. Leaf total phenols, flavonoids, and cupric reducing antioxidant capacity (CUPRAC) values were highest in red net and in unshaded conditions. Trolox equivalent antioxidant capacity (TEAC) values were highest in red net and lowest in silver net. In conclusion, compared with unshaded conditions, shade nets resulted in improved bell pepper plant growth and leaf gas exchange. These responses were due primarily to the reduced leaf and root zone temperatures under shaded conditions, regardless of the color of shade net. The differences in plant growth and function due to color of shade net were inconsistent or minor for most of the plant variables measured.
\end{abstract}

Bell pepper (Capsicum annum L.) yield and quality may be severely impacted under high temperatures, particularly during late

Received for publication 21 May 2019. Accepted for publication 27 June 2019

Financial support was provided by the Georgia Agricultural Experiment Stations. This material is based upon work that is supported by the National Institute of Food and Agriculture, U.S. Department of Agriculture, under award number 2014-33610-22604.

We thank Jesús Bautista, Gunawati Gunawan, and Nélida Bautista for their invaluable technical support and Jason Brock of the Plant Disease Clinic, University of Georgia, for identification of plant diseases. We appreciate the thorough review of the manuscript by Erick Smith, André Luiz Biscaia Ribeiro da Silva, and the anonymous reviewers. Mention of trade names in this publication does not imply endorsement by the University of Georgia of products named, nor criticism of similar ones not mentioned. J.C.D.-P. is the corresponding author. E-mail: jcdiaz@, uga.edu. spring and early summer in the southeast United States. High air and root zone temperatures reduce bell pepper yield and increase the incidence of fruit disorders such as blossom-end rot and sunscald (Díaz-Pérez, 2010; Taylor and Locascio, 2004).

Shade nets are used in tropical and subtropical countries for production of horticultural crops (El-Aidy et al., 1993; Ilic et al., 2012; Kittas et al., 2012; Rylski and Spigelman, 1986; Shahak, 2008). Shade nets protect horticultural crops from excessive radiation, wind, hail, and birds. There is limited information on the use of shade nets for vegetable field production in the United States (Boyhan et al., 2008; Roberts and Anderson, 1994; Russo, 1993). Shade nets may influence plant growth by reducing solar radiation intensity and by modifying other microclimatic conditions (Mahmood et al., 2018). Research in Georgia on bell pepper under black shade nets has shown that with increased shade level, total plant leaf area, individual leaf area, and individual leaf weight increased, whereas number of leaves per plant and specific leaf weight declined (Díaz-Pérez, 2013).

Although black nets are most commonly used, there has been increased interest in colored nets. Colored nets may influence plant growth, yield, and fruit quality because of their ability to modify both light quality and quantity (Arthurs et al., 2013; Fallik, 2009; Ilic et al., 2017). Regardless of net color, shade nets reduce solar radiation with concomitant reductions in air, plant, and soil temperatures. Use of colored shading nets has shown benefits in various horticultural crops, although there is limited information on bell pepper (Stamps, 2009). The objective of our work was to determine the effects of colored shade nets on plant growth, leaf gas exchange, and leaf pigments of field-grown bell pepper.

\section{Materials and Methods}

This study was conducted at the Horticulture Farm, University of Georgia (lat. $31.4803^{\circ} \mathrm{N}$, long. $83.5211^{\circ} \mathrm{W}$ ), Tifton, GA during the spring seasons of 2015 and 2016. The soil was a Tifton Sandy Loam (a fine, loamy-siliceous, thermic Plinthic Kandiudults) with a $\mathrm{pH}$ of 6.5 . Before laying mulch with a mulch-laying machine (Kenco Manufacturer, Ruskin, FL), the soil was fertilized with $\mathrm{N}, \mathrm{P}$, and $\mathrm{K}$ at $50,22.0$, and $41.5 \mathrm{~kg} \cdot \mathrm{ha}^{-1}$, respectively, using a $10-10-10$ granular fertilizer (Rainbow Plant Food, Montgomery, AL). Fertilizer was incorporated into the soil. Plastic film mulch [black, low-density polyethylene with a slick surface texture, $1.52 \mathrm{~m}$ wide and $25 \mu \mathrm{m}$ thick (Intergro, Clearwater, FL)] was laid. Drip irrigation tape $[30 \mathrm{~cm}$ emitter spacing and a $12.6 \mathrm{~mL} \cdot \mathrm{min}^{-1}$ emitter flow at 0.55 bar of pressure (Aqua traxx; Toro, Abilene, TX)] was placed $5 \mathrm{~cm}$ deep in the center of the bed.

Experimental design was a randomized complete block with four replications and five shade treatments (four colored nets and an unshaded control). Colored nets were black ( $47 \%$ shade), red ( $42 \%$ shade), silver ( $40 \%$ shade), and white ( $41 \%$ shade) (Fig. 1$)$. These values of shade level are as reported by the manufacturer (Green-tek, Janesville, WI) and are within the optimal shade level $(30 \%$ to $46 \%$ shade) for bell pepper (Diaz-Pérez, 2014). Each shade net was placed on a wooden rectangular structure $(15 \mathrm{~m}$ wide $\times$ $6 \mathrm{~m}$ long $\times 5 \mathrm{~m}$ high). Experimental design was a randomized complete block with four replications and 10 treatments [5 shade treatments (black, red, silver, and white nets and an unshaded control; Green-tek, Janesville, WI)]. Shade nets reduced solar radiation by about $40 \%$.

Bell pepper ('PS 09979325') transplants were produced in a greenhouse using peatbased medium (All Purpose Mix, Pro-Mix; Quakertown, PA) and polystyrene 200-cell $(2.5 \times 2.5 \mathrm{~cm}$ cell $)$ trays. Plants were established on individual raised beds (formed on 1.8-m centers; $0.76 \mathrm{~m}$ wide). The length of 
the field experimental plot was $6 \mathrm{~m}$. Sixweek-old transplants were planted on $12 \mathrm{Apr}$. 2015 and 20 Apr. 2016 in two rows (staggered) per bed, with a $30 \mathrm{~cm}$ separation between plants and $36 \mathrm{~cm}$ separation between rows (40 plants per plot). About $240 \mathrm{~mL}$ of starter fertilizer solution (555 ppm N; 821 ppm P; 0 ppm K) was applied directly to the base of each transplant. Starting three weeks after transplanting, plants were fertilized weekly through the drip system. Total major nutrients applied were $200 \mathrm{~kg} \cdot \mathrm{ha}^{-1}$ [nitrogen $(\mathrm{N})$ ], $22 \mathrm{~kg} \cdot \mathrm{ha}^{-1}$ [phosphorus (P)], and 191 $\mathrm{kg} \cdot \mathrm{ha}^{-1}$ [potassium $\left.(\mathrm{K})\right]$. The crop was grown following the recommendations of the University of Georgia Extension Service.

Plants were irrigated with an amount of water equivalent to $100 \%$ crop evapotranspiration (ETc), which was calculated by multiplying the reference evapotranspiration (ETo) by the crop factor (dependent on the crop stage of development). Water was applied when cumulative ETc was $1.2 \mathrm{~mm}$, which corresponded to about every 2 to $3 \mathrm{~d}$ in mature plants (mean ETo was $5 \mathrm{~mm} \cdot \mathrm{d}^{-1}$ ).

Microenviroment. Air temperature and relative humidity were measured periodically during the season (both in 2015 and 2016) with dataloggers (HOBO, MX2301A; Instru-

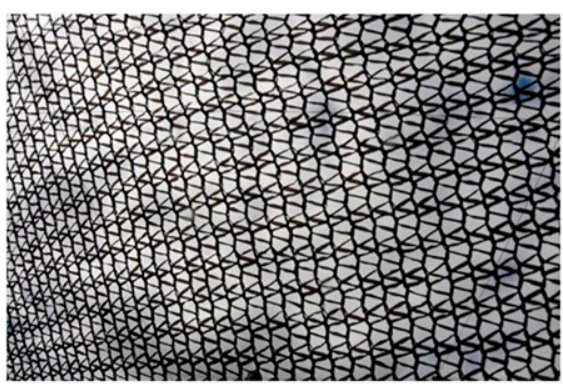

Black

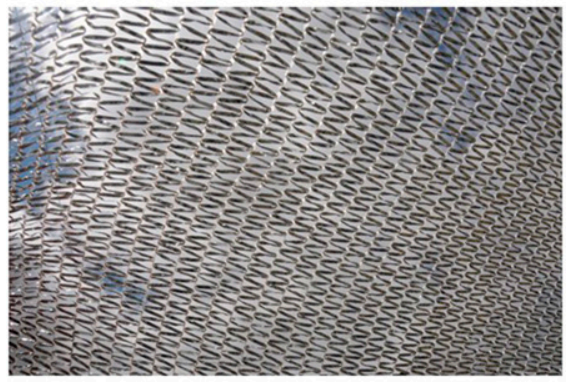

Silver mart, Burlington, VT). Data for white treatment were not collected due to a datalogger malfunction. Midday canopy temperature was measured on clear days with an infrared (IR) thermometer on 18 and 25 May, and 3 June 2015 (three measurements per experimental plot). Root zone temperature $(8 \mathrm{~cm}$ deep) at midday was measured manually with a digital thermometer the same days as canopy temperature. The ETo and rainfall data were obtained from a nearby University of Georgia weather station (less than $300 \mathrm{~m}$ ).

Plant growth and chlorophyll index. Plant height and stem diameter were measured weekly for 5 weeks from mid-May to midJune in three mature plants per plot. Chlorophyll indices (CI) were measured weekly on six leaves per plot using a chlorophyll meter (Chlorophyll Meter SPAD-502; Minolta Co., Ltd., Ramsey, NJ).

Plant diseases. Plants were monitored weekly for presence of Phytophthora blight (caused by Phytophthora capsici), Southern blight (caused by Sclerotium rolfsii), and Tomato spotted wilt [caused by Tomato spotted wilt virus (TSWV)]. Etiology of plant diseases was evaluated at the Plant Disease Clinic, University of Georgia, Tifton Campus. Presence of TSWV in symptomatic

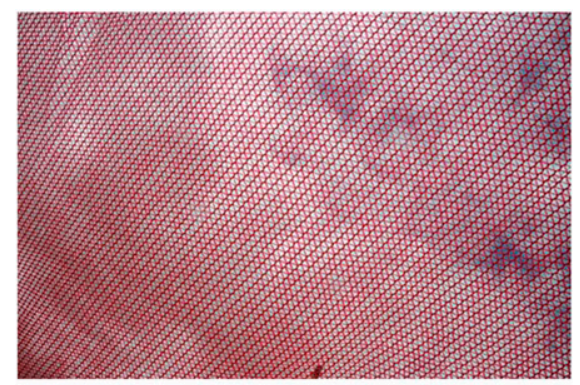

Red

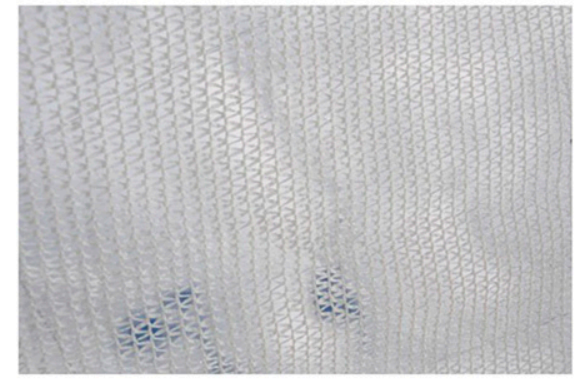

White

Fig. 1. Colored shade nets for bell pepper production (Tifton, GA, Spring 2015 and 2016).

plants was confirmed by enzyme-linked immunosorbent assay (ELISA).

Leaf gas exchange and Photosystem II efficiency. Simultaneous measurements of leaf gas exchange (net photosynthesis, $g_{\mathrm{S}}$, internal $\mathrm{CO}_{2}$ concentration and transpiration), leaf temperature, photosynthetically active radiation $(P A R)$, and fluorescence determined as Photosystem II (PSII) efficiency were made with an IR gas analyzer (LI-COR 6400 IRGA with an integrated 6400-40 leaf chamber fluorometer; LI-COR, Inc., Lincoln, NE). PSII efficiency is the fraction of absorbed PSII photons used in photochemistry, and it is measured with a light-adapted leaf (LI-COR, 2003). Water use efficiency was calculated as the ratio between net photosynthesis and transpiration. Air flow rate was set at $300 \mu \mathrm{mol} \cdot \mathrm{m}^{-2} \cdot \mathrm{s}^{-1}$ on the reference side. The $\mathrm{CO}_{2}$ concentration was set at $400 \mu \mathrm{mol} \cdot \mathrm{mol}^{-1}$ with a $\mathrm{CO}_{2}$ mixer and a $\mathrm{CO}_{2}$ tank. Measurements were conducted in developed plants on clear days (unshaded conditions $P A R>1900 \mu \mathrm{mol} \cdot \mathrm{m}^{-2} \cdot \mathrm{s}^{-1}$ ) at 1200 to $1500 \mathrm{HR}$ using two developed and fully exposed leaves per plot.

Leaf chemical composition. Six leaves per treatment were collected on 29 May and 5 June 2015 and analyzed individually for chemical composition. Carotenoids and chlorophyll (Chl) $a$ and $b$ were determined in fresh leaves. Leaf tissue was ground in acetone $(90 \% \mathrm{v} / \mathrm{v})$, filtered, and taken to a volume of $50 \mathrm{~mL}$ (Ilic et al., 2012; Lichtenthaler, 1987). Pigments concentrations were calculated from the absorbance of the extract at 470, 645, and $663 \mathrm{~nm}$. Total phenols were determined as a measure of total antioxidant capacity following the Follin-Ciocalteau method (Singleton et al., 1999), and data were expressed as gallic acid equivalents. Antioxidant capacity was determined by CUPRAC and TEAC methods (Barros et al., 2007; Castro-Concha et al., 2014). Total flavonoid concentration was determined by the aluminum chloride colorimetric method and expressed in quercetin equivalents (Rawat et al., 2014).

\section{Results and Discussion}

Microclimatological factors. Seasonal averages of air temperature and relative humidity for 2015 and 2016 are shown in Tables 1 and 2. In 2015, minimal air temperatures were highest under the black net and lowest in unshaded conditions (Table 1). Mean air temperature was lowest under the black net

Table 1. Effect of colored shade nets on air and canopy temperature, root zone temperature (RZT), and relative humidity in bell pepper (Tifton, GA, Spring 2015).

\begin{tabular}{|c|c|c|c|c|c|c|c|c|}
\hline \multirow[b]{2}{*}{ Shade } & \multicolumn{3}{|c|}{ Air temp $\left({ }^{\circ} \mathrm{C}\right)$} & \multirow{2}{*}{$\begin{array}{l}\text { Midday canopy } \\
\text { temp. }\left({ }^{\circ} \mathrm{C}\right)\end{array}$} & \multirow[b]{2}{*}{ Midday RZT $\left({ }^{\circ} \mathrm{C}\right)$} & \multicolumn{3}{|c|}{ Relative humidity $(\%)$} \\
\hline & Minimal & Mean & Maximal & & & Minimal & Mean & Maximal \\
\hline$\overline{\text { Black }}$ & $22.32 \mathrm{a}^{\mathrm{z}}$ & $27.0 \mathrm{c}$ & $33.1 \mathrm{~b}$ & $27.1 \mathrm{~b}$ & $34.0 \mathrm{~b}$ & $49.5 \mathrm{a}$ & $69.9 \mathrm{a}$ & $87.0 \mathrm{~b}$ \\
\hline Red & $22.28 \mathrm{ab}$ & $27.1 \mathrm{~b}$ & $33.1 \mathrm{~b}$ & $27.0 \mathrm{~b}$ & $34.9 \mathrm{~b}$ & $46.8 \mathrm{c}$ & $65.9 \mathrm{~d}$ & $82.8 \mathrm{c}$ \\
\hline Silver & $22.26 \mathrm{~b}$ & $27.1 \mathrm{~b}$ & $33.0 \mathrm{c}$ & $27.2 \mathrm{~b}$ & $34.9 \mathrm{~b}$ & $48.3 \mathrm{~b}$ & $68.8 \mathrm{~b}$ & $87.3 \mathrm{a}$ \\
\hline White & $n d^{y}$ & nd & nd & $27.6 \mathrm{~b}$ & $35.2 \mathrm{~b}$ & nd & nd & nd \\
\hline Unshaded & $22.17 \mathrm{c}$ & $27.2 \mathrm{a}$ & $33.9 \mathrm{a}$ & $29.4 \mathrm{a}$ & $37.1 \mathrm{a}$ & $45.7 \mathrm{~d}$ & $67.6 \mathrm{c}$ & $86.9 \mathrm{~b}$ \\
\hline$P$ & $<0.0001$ & $<0.0001$ & $<0.0001$ & $<0.001$ & $<0.0001$ & $<0.0001$ & $<0.0001$ & $<0.0001$ \\
\hline
\end{tabular}

${ }^{\mathrm{z}}$ Means followed by the same letter are not significantly different based on Fisher's protected least significant difference test at $95 \%$ confidence.

${ }^{\mathrm{y}}$ nd $=$ not determined. 
Table 2. Effect of colored shade nets on air temperature and relative humidity in bell pepper (Tifton, GA, Spring 2016).

\begin{tabular}{|c|c|c|c|c|c|c|}
\hline \multirow[b]{2}{*}{ Shade } & \multicolumn{3}{|c|}{ Air temp $\left({ }^{\circ} \mathrm{C}\right)$} & \multicolumn{3}{|c|}{ Relative humidity (\%) } \\
\hline & Minimal & Mean & Maximal & Minimal & Mean & Maximal \\
\hline$\overline{\text { Black }}$ & $20.52 b^{z}$ & $26.2 \mathrm{c}$ & $31.8 \mathrm{c}$ & $43.2 \mathrm{a}$ & $62.5 \mathrm{a}$ & $82.7 \mathrm{a}$ \\
\hline Red & $20.49 \mathrm{c}$ & $26.3 \mathrm{~b}$ & $32.1 \mathrm{~b}$ & $39.7 \mathrm{c}$ & $58.4 \mathrm{c}$ & $79.0 \mathrm{~b}$ \\
\hline Silver & $20.56 \mathrm{~b}$ & $26.4 \mathrm{~b}$ & $31.9 \mathrm{c}$ & $40.9 \mathrm{~b}$ & $60.5 \mathrm{~b}$ & $81.9 \mathrm{a}$ \\
\hline Unshaded & $20.66 \mathrm{a}$ & $26.6 \mathrm{a}$ & $32.6 \mathrm{a}$ & $41.3 \mathrm{~b}$ & $56.0 \mathrm{~d}$ & $71.5 \mathrm{c}$ \\
\hline$P$ & $<0.0001$ & $<0.0001$ & $<0.0001$ & $<0.0001$ & $<0.0001$ & $<0.0001$ \\
\hline
\end{tabular}

${ }^{\mathrm{z}}$ Means followed by the same letter are not significantly different based on Fisher's protected least significant difference test at $95 \%$ confidence.

Table 3. Effect of colored shade nets on plant growth, leaf chlorophyll index, air temperature, and incidence of soil-borne diseases in bell pepper (Tifton, GA, Spring 2015).

\begin{tabular}{|c|c|c|c|c|}
\hline Shade & $\mathrm{Ht}(\mathrm{cm})$ & Stem diam (mm) & Chlorophyll index & $\begin{array}{c}\text { Incidence soil-borne } \\
\text { diseases }(\%)\end{array}$ \\
\hline$\overline{\text { Black }}$ & $39.8 \mathrm{a}^{\mathrm{z}}$ & $10.0 \mathrm{a}$ & $66.2 \mathrm{~b}$ & $26 \mathrm{ab}$ \\
\hline Red & $38.0 \mathrm{a}$ & $9.8 \mathrm{a}$ & $68.4 \mathrm{ab}$ & $25 \mathrm{ab}$ \\
\hline Silver & $41.1 \mathrm{a}$ & $10.1 \mathrm{a}$ & $69.0 \mathrm{a}$ & $29 \mathrm{ab}$ \\
\hline White & $38.0 \mathrm{a}$ & $10.5 \mathrm{a}$ & $68.9 \mathrm{a}$ & $23 \mathrm{~b}$ \\
\hline Unshaded & $18.6 \mathrm{~b}$ & $6.9 \mathrm{~b}$ & $69.1 \mathrm{a}$ & $46 \mathrm{a}$ \\
\hline$P$ & $<0.0001$ & $<0.0001$ & $<0.0001$ & 0.004 \\
\hline
\end{tabular}

${ }^{\mathrm{z}}$ Means followed by the same letter are not significantly different based on Fisher's protected least significant difference test at $95 \%$ confidence.

Table 4. Effect of colored shade nets on bell pepper plant growth, leaf chlorophyll index, air temperature, and incidence of soil-borne diseases (Tifton, GA, Spring 2016).

\begin{tabular}{|c|c|c|c|c|c|}
\hline \multirow[b]{2}{*}{ Shade } & \multirow[b]{2}{*}{$\begin{array}{l}\text { Stem diam } \\
(\mathrm{mm})\end{array}$} & \multirow[b]{2}{*}{ Top fresh wt (g) } & \multirow[b]{2}{*}{$\begin{array}{l}\text { Chlorophyll } \\
\text { index }\end{array}$} & \multicolumn{2}{|c|}{ Incidence soil-borne disease $(\%)$} \\
\hline & & & & $\begin{array}{c}\text { Southern } \\
\text { blight }\end{array}$ & $\begin{array}{c}\text { Phytophthora } \\
\text { blight }\end{array}$ \\
\hline$\overline{\text { Black }}$ & $11.9 \mathrm{ab}^{\mathrm{z}}$ & $373 \mathrm{ab}$ & $60.4 \mathrm{~b}$ & 13.1 & $1.9 \mathrm{~b}$ \\
\hline Red & $12.0 \mathrm{ab}$ & $393 \mathrm{ab}$ & $60.7 \mathrm{~b}$ & 15.6 & $1.3 \mathrm{~b}$ \\
\hline Silver & $12.8 \mathrm{a}$ & $431 \mathrm{a}$ & $60.7 \mathrm{~b}$ & 14.7 & $0.3 \mathrm{~b}$ \\
\hline White & $12.0 \mathrm{ab}$ & $446 \mathrm{a}$ & $61.4 \mathrm{~b}$ & 13.4 & $2.2 \mathrm{~b}$ \\
\hline Unshaded & $11.2 \mathrm{~b}$ & $291 \mathrm{~b}$ & $62.8 \mathrm{a}$ & 18.8 & $13.9 \mathrm{a}$ \\
\hline$P$ & $<0.0001$ & 0.008 & $<0.0001$ & 0.288 & 0.0005 \\
\hline
\end{tabular}

${ }^{\mathrm{z}}$ Means followed by the same letter are not significantly different based on Fisher's protected least significant difference test at $95 \%$ confidence.

and highest in unshaded conditions. Maximal air temperature was lowest under the silver net and highest under unshaded conditions. Midday RZTs were highest in the unshaded treatment, and there were no RZT differences between shading nets (Table 1). Root zone temperature increased with increasing $P A R$ $\left(r^{2}=0.936\right)$ under the shade net treatments, while air temperature was unrelated to $P A R$. Minimal, mean, and maximal relative humidity was among the lowest under the red net and in unshaded conditions. In 2016, minimal air temperatures were lowest under the red net and highest in unshaded conditions (Table 2). Mean air temperature was lowest under the black net and highest in unshaded conditions, while maximal air temperature was lowest under the black and silver nets and had highest values in the unshaded treatment. Minimal relative humidity was lowest under the red net and highest under the black net. Mean relative humidity was lowest in unshaded conditions and highest under the black net. Maximal relative humidity was lowest under unshaded conditions and highest under the black net.

Shade nets affect the quality and quantity of solar radiation received by the crop as well as the air and soil temperature under the net. In the present study, the differences in air temperatures between shade net treatments were smaller compared with the differences in RZT. In a study in Florida using shadehouse structures with full cov- ering, daily maximum air temperatures were higher inside shadehouses with red, blue, and pearl nets compared with black nets or uncovered conditions (Arthurs et al., 2013). In the present study in which shade structures were rectangular prisms and the net covered only the upper portion of the structure, maximal air temperature was lowest under the silver net and highest under unshaded conditions. In a study in Hungary using colored shade nets over pepper, air temperature showed relatively little changes in response to colored shade nets, and air temperature decreased with increasing shade level (Ombódi et al., 2015). The reduction of solar radiation $(P A R$, IR, and longwave radiation) under shade nets probably contributed to the reduced air temperatures and reduced RZTs under shaded conditions, compared with unshaded conditions. Reduced air and leaf temperature under shade nets resulted in diminished plant transpiration due to reduced evaporative demand, compared with the unshaded treatment.

Plant growth and chlorophyll index. In 2015 , plant height and stem diameter were reduced in the unshaded treatment (Table 3 ), and there were no differences in plant height and stem diameter among shade nets. Chlorophyll index was reduced under the black net. In 2016, stem diameter and top fresh weight were reduced in unshaded conditions (Table 4). Chlorophyll index was the highest in unshaded conditions, while there were no differences in chlorophyll indexes among shade nets.

Light is essential for photosynthesis in plants, but it may also influence plant growth and development through the action of several photoreceptors such as phytochromes (Smith, 2000). Red nets have been found to reduce the red/far-red ratio resulting in enhanced vegetative growth in various crops (Oren-Shamir et al., 2001; Shahak, 2008). In this study, shade nets modified light quantity (i.e., $P A R$ ) received by bell pepper plants; the effect of shade net treatments on light quality was not measured. Black nets and colored nets have been reported to influence plant growth of bell pepper and other vegetables (Díaz-Pérez, 2013; Ilic et al., 2017; Ombódi et al., 2015; Shahak, 2008). In greenhousegrown eggplant, plant height, leaf number, total leaf area, individual leaf area, and plant fresh weight were increased under shading compared with an open field (Aied et al., 2017).

Plant diseases. In 2015, the incidence of soil-borne diseases (unidentified diseases) was increased in unshaded conditions (Table $3)$. In 2016, the incidence of southern blight was unaffected by shade treatments, while the incidence of Phytophthora blight was increased in unshaded conditions (Table 4). The incidence of Tomato spotted wilt incidence was small and similar among shade treatments $($ mean $=0.51 \%)$. 
Table 5. Effect of colored shade nets on leaf net photosynthesis $\left(\mathrm{P}_{\text {net }}\right)$, stomatal conductance $\left(g_{\mathrm{S}}\right)$, internal $\mathrm{CO}_{2}$, photosystem II (PSII) efficiency, photosynthetic water use efficiency $(W U E)$, photosynthetically active radiation $(P A R)$, and leaf temperature $\left(\mathrm{T}_{\text {leaf }}\right)$ in bell pepper (Tifton, GA, Spring 2015$)$.

\begin{tabular}{|c|c|c|c|c|c|c|c|}
\hline Shade & $\begin{array}{l}\text { Net } \\
\text { photosynthesis } \\
\left(\mu \mathrm{mol} \cdot \mathrm{m}^{-2} \cdot \mathrm{s}^{-1}\right)\end{array}$ & $\begin{array}{c}g_{\mathrm{S}} \\
\left(\mathrm{mmol} \cdot \mathrm{m}^{-2} \cdot \mathrm{s}^{-1}\right)\end{array}$ & $\begin{array}{l}\text { Internal } \mathrm{CO}_{2} \\
\left(\mu \mathrm{mol} \cdot \mathrm{mol}^{-1}\right)\end{array}$ & $\begin{array}{c}\text { PSII } \\
\text { efficiency }^{y}\end{array}$ & $W U E$ & $\begin{array}{c}P A R \\
\left(\mu \mathrm{mol} \cdot \mathrm{m}^{-2} \cdot \mathrm{s}^{-1}\right)\end{array}$ & $\mathrm{T}_{\text {leaf }}\left({ }^{\circ} \mathrm{C}\right)$ \\
\hline Black & $28.4 \mathrm{ab}^{\mathrm{z}}$ & $756 \mathrm{ab}$ & $306.8 \mathrm{a}$ & $0.260 \mathrm{a}$ & 1.68 & $985 \mathrm{~d}$ & $31.8 \mathrm{~b}$ \\
\hline Red & $28.0 \mathrm{ab}$ & $769 \mathrm{ab}$ & $304.6 \mathrm{a}$ & $0.231 \mathrm{a}$ & 1.67 & $1064 \mathrm{c}$ & $31.8 \mathrm{~b}$ \\
\hline White & $26.5 \mathrm{bc}$ & $613 b c$ & $290.9 a b$ & $0.234 \mathrm{a}$ & 1.75 & $1135 \mathrm{~b}$ & $33.2 \mathrm{a}$ \\
\hline Unshaded & $25.1 \mathrm{c}$ & $515 \mathrm{c}$ & $280.2 \mathrm{~b}$ & $0.161 \mathrm{~b}$ & 1.74 & $1851 \mathrm{a}$ & $34.2 \mathrm{a}$ \\
\hline$P$ & 0.0004 & $<0.0001$ & 0.0011 & $<0.0001$ & 0.057 & $<0.0001$ & $<0.0001$ \\
\hline
\end{tabular}

${ }^{\mathrm{z}}$ Means followed by the same letter are not significantly different based on Fisher's protected least significant difference test at $95 \%$ confidence.

${ }^{\mathrm{y}}$ Photosystem II (PSII) efficiency. It is the fraction of absorbed PSII photons that are used in photochemistry and is used as an indicator of plant stress.

Table 6. Effect of colored shade nets on leaf net photosynthesis $\left(\mathrm{P}_{\text {net }}\right)$, stomatal conductance $\left(g_{\mathrm{S}}\right)$, internal $\mathrm{CO}_{2}$, photosystem II (PSII) efficiency, photosynthetic water use efficiency $(W U E)$, photosynthetically active radiation $(P A R)$, and leaf temperature $\left(\mathrm{T}_{\text {leaf }}\right)$ in bell pepper (Tifton, GA, Spring 2016$)$.

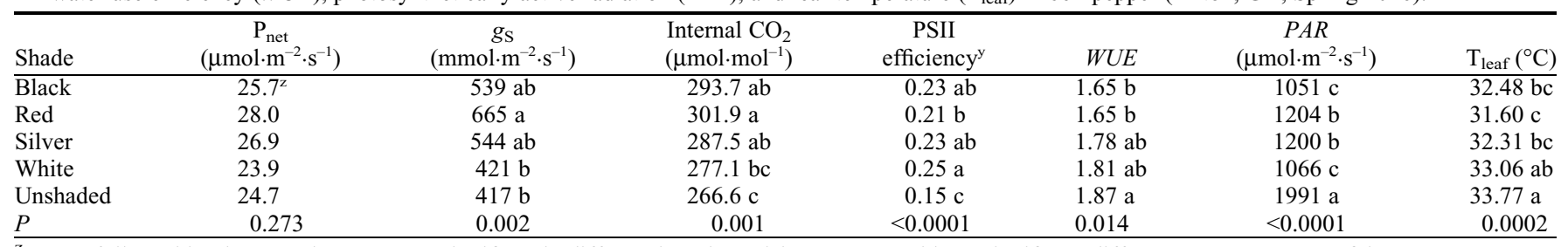

${ }^{\mathrm{z}}$ Means followed by the same letter are not significantly different based on Fisher's protected least significant difference test at $95 \%$ confidence.

${ }^{\mathrm{y}}$ Photosystem II (PSII) efficiency. It is the fraction of absorbed PSII photons that are used in photochemistry and is used as an indicator of plant stress.
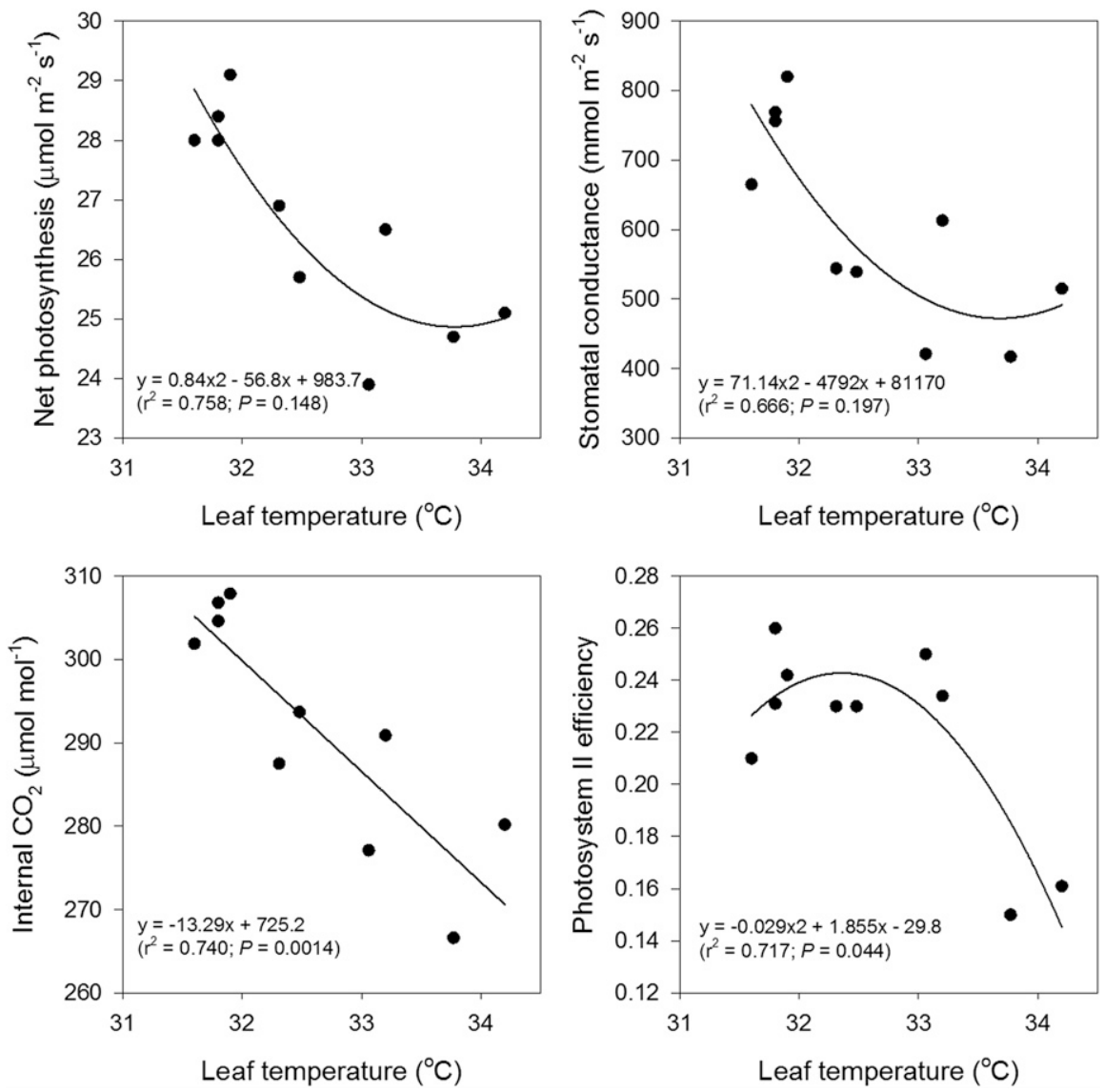

Fig. 2. Leaf net photosynthesis, stomatal conductance, internal $\mathrm{CO}_{2}$ concentration, and photosystem II efficiency as influenced by midday leaf temperatures in bell pepper plants under colored shade nets (Tifton, GA, Spring 2015 and 2016).

Light level may affect soil microbial populations under natural and field conditions. The densities of Pythium spp. have been found to decrease under forest canopy gaps (Reinhart et al., 2010). Incidence of
Phytophthora blight has been reported to decrease with increased shade level in bell pepper (Díaz-Pérez, 2014). In the present study, it is unclear whether the influence of shade on incidence of Phytophthora blight was due to a direct effect of light level on the pathogen, the host, or their interaction with the environment.

The influences of shade nets on plant diseases are little understood. In pepper, under colored shade nets, leaf coverage by powdery mildew (Leveillula taurica) was found to augment with increasing shade level; black, blue-silver, green, and red nets were associated with reduced powdery mildew levels (Elad et al., 2007). Interestingly, the incidences of southern blight and Tomato spotted wilt in the present study were unaffected by shade treatments, indicating that bell pepper plant diseases may respond differently to shade conditions (i.e., light quantity and quality). Shade nets probably provided some relief from plant water stress to infected plants having restricted capacity for water uptake and transport due to an impaired vascular system (Aguirreolea et al., 1995).

Gas exchange. In 2015, leaf net photosynthesis and $g_{\mathrm{S}}$ were highest under silver net and lowest in unshaded conditions (Table 5). Internal $\mathrm{CO}_{2}$ concentration and PSII efficiency were lowest in unshaded conditions. The WUE was not significantly different among treatments. The $P A R$ ranged from $1851 \mu \mathrm{mol} \cdot \mathrm{m}^{-2} \cdot \mathrm{s}^{-1}$ in the unshaded treatment to $985 \mu \mathrm{mol} \cdot \mathrm{m}^{-2} \cdot \mathrm{s}^{-1}$ in the black net treatment. Leaf temperature was highest in the white net and unshaded treatments. In 2016, net photosynthesis was unaffected by shade net treatments (Table 6). Stomatal conductance and internal $\mathrm{CO}_{2}$ were highest under the red net and among the lowest under unshaded conditions and the white net. The PSII efficiency was highest under the white net and lowest in unshaded conditions. The $W U E$ was increased in unshaded conditions. The $P A R$ ranged from $1991 \mu \mathrm{mol} \cdot \mathrm{m}^{-2} \cdot \mathrm{s}^{-1}$ in the unshaded treatment to $1051 \mu \mathrm{mol} \cdot \mathrm{m}^{-2} \cdot \mathrm{s}^{-1}$ 


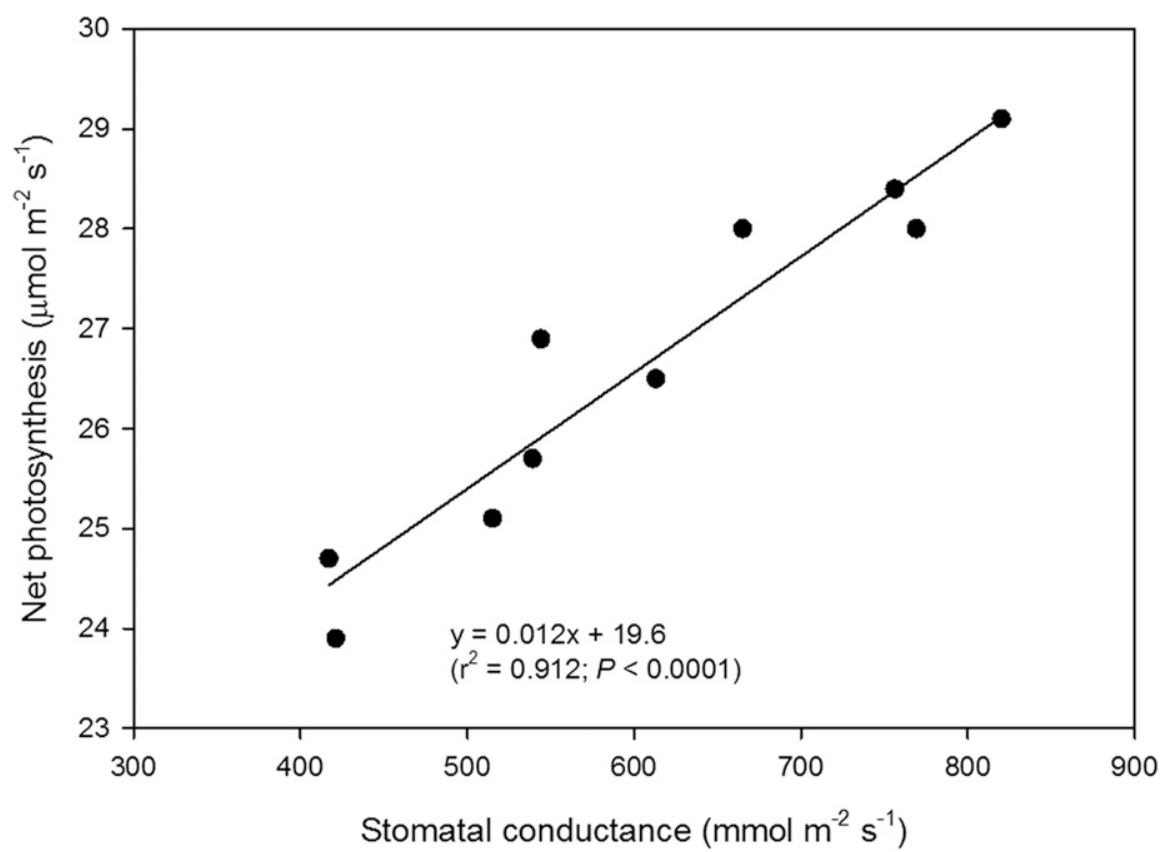

Fig. 3. Relationship between leaf net photosynthesis and stomatal conductance in bell pepper plants under colored shade nets (Tifton, GA, Spring 2015 and 2016).

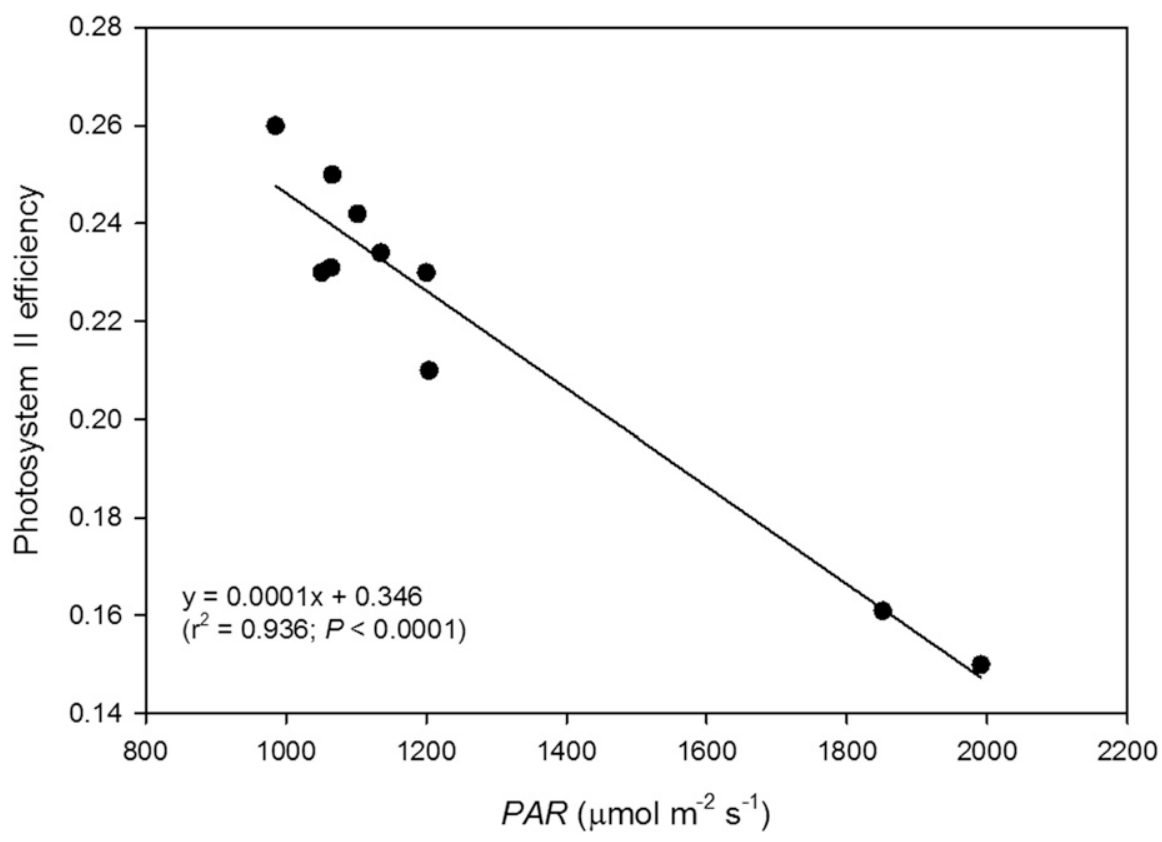

Fig. 4. Leaf photosystem II efficiency as influenced by photosynthetically active radiation $(P A R)$ in bell pepper plants under colored shade nets (Tifton, GA, Spring 2015 and 2016). in the black treatment. Leaf temperature was highest in the unshaded treatment and lowest under the red net.

Mean leaf temperature at midday increased with increasing $P A R$ under the nets $\left(r^{2}=0.596 ; P=0.009\right)$. However, when data from unshaded conditions were not considered in the statistical analysis, leaf temperature showed no relationship with $P A R$ under the nets, indicating that leaf temperature had no relationship with the differences in $P A R$ among mulches. Leaf net photosynthesis, $g_{\mathrm{S}}$, internal $\mathrm{CO}_{2}$, and PS II efficiency decreased with increasing values of leaf temperature (Fig. 2). Leaf net photosynthesis increased with increasing rates of leaf $g_{\mathrm{S}}$ (Fig. 3). Photosystem II efficiency decreased with increasing $P A R$ values (Fig. 4). Among shade nets, there was no relationship between internal $\mathrm{CO}_{2}$ and $P A R$.

Leaf gas exchange responses in the present study were probably highly influenced by leaf temperature. Differences in leaf temperature among shade net treatments are because of differences in solar radiation captured by leaves. Little IR is absorbed by leaves at wavelengths below $2000 \mathrm{~nm}$, but more than $97 \%$ of solar radiation is absorbed at wavelengths above $7000 \mathrm{~nm}$ (Larcher, 1995).

Photosynthesis can be controlled by stomatal and nonstomatal factors (Jones, 1992). Occurrence of high leaf temperature was probably associated with high solar radiation and plant water stress due to low leaf transpiration and low $g_{\mathrm{S}}$. The linear relationship between net photosynthesis and $g_{\mathrm{S}}$ in the present study indicates that there was a large stomatal control of photosynthesis under the various $P A R$ levels. In a field study on bell pepper under different shade levels, net photosynthesis, transpiration, $g_{\mathrm{S}}$, and water use efficiency decreased quadratically and internal $\mathrm{CO}_{2}$ concentration and PSII efficiency increased quadratically with increased shade level. The authors concluded that leaf gas exchange responses were also highly dependent on stomatal factors (Díaz-Pérez, 2013). In a study on lemon trees (Citrus limon), shaded trees had reduced transpiration (sap flow), reduced trunk shrinkage, reduced leaf water potential, and increased water-use efficiency, indicating that shaded trees showed decreased water stress compared with unshaded trees (Alarcon et al., 2006).

Table 7. Effect of colored shade nets on leaf chemical composition in bell pepper (Tifton, GA, Spring 2015).

\begin{tabular}{|c|c|c|c|c|c|c|c|c|}
\hline Shade & $\begin{array}{l}\text { Carotenoids } \\
\left(\mathrm{mg} \cdot \mathrm{L}^{-1}\right)\end{array}$ & $\begin{array}{c}\text { Chl } a^{\mathrm{y}} \\
\left(\mathrm{mg} \cdot \mathrm{L}^{-1}\right)\end{array}$ & $\begin{array}{c}\text { Chl } b^{\mathrm{y}} \\
\left(\mathrm{mg} \cdot \mathrm{L}^{-1}\right)\end{array}$ & Chl $a / b$ & CUPRAC $^{\mathrm{x}}(\mu \mathrm{M})$ & $\mathrm{TEAC}^{\mathrm{w}}(\mu \mathrm{M})$ & $\begin{array}{c}\text { Total phenols } \\
\text { [gallic acid equiv. } \\
\left.\left(\mathrm{mg} \cdot \mathrm{L}^{-1}\right)\right]\end{array}$ & $\begin{array}{c}\text { Flavonoids } \\
\text { [Quercetin equiv. } \\
\left.\left(\mathrm{mg} \cdot \mathrm{mL}^{-1}\right)\right]\end{array}$ \\
\hline Black & $1.10 \mathrm{ab}^{\mathrm{z}}$ & $4.47 \mathrm{bc}$ & 2.00 & 2.28 & $8153 \mathrm{c}$ & $13606 \mathrm{~d}$ & $714 \mathrm{c}$ & $456 \mathrm{~b}$ \\
\hline Red & $1.19 \mathrm{a}$ & $4.84 \mathrm{a}$ & 2.13 & 2.28 & 10093 a & $23425 \mathrm{a}$ & $1016 \mathrm{a}$ & $798 \mathrm{a}$ \\
\hline Silver & $1.17 \mathrm{a}$ & $4.79 \mathrm{a}$ & 2.10 & 2.30 & $8867 \mathrm{~b}$ & $11372 \mathrm{e}$ & 794 b & $472 \mathrm{~b}$ \\
\hline White & $1.18 \mathrm{a}$ & $4.71 \mathrm{ab}$ & 2.04 & 2.33 & $8174 \mathrm{c}$ & $19615 \mathrm{c}$ & $720 \mathrm{c}$ & $491 \mathrm{~b}$ \\
\hline Unshaded & $1.06 \mathrm{~b}$ & $4.31 \mathrm{c}$ & 1.90 & 2.35 & $9981 \mathrm{a}$ & $22008 \mathrm{~b}$ & $1017 \mathrm{a}$ & $767 \mathrm{a}$ \\
\hline$P$ & 0.025 & 0.0015 & 0.143 & 0.170 & $<0.0001$ & $<0.0001$ & $<0.0001$ & $<0.0001$ \\
\hline
\end{tabular}

${ }_{\mathrm{z}}$ Means followed by the same letter are not significantly different based on Fisher's protected least significant difference test at $95 \%$ confidence.

${ }^{\mathrm{y}} \mathrm{Chl} a=$ Chlorophyll $a$; Chl $b=$ Chlorophyll $b$.

${ }^{\mathrm{x}}$ CUPRAC $=$ cupric reducing antioxidant capacity.

${ }^{\mathrm{w}} \mathrm{TEAC}=$ trolox equivalent antioxidant capacity. 
Leaf chemical composition. Leaf total carotenoids were lowest in unshaded conditions and there were no differences in total carotenoids among the shade nets (Table 7). Chlorophyll $a$ concentrations were highest in plants under the red and silver nets and lowest in unshaded conditions. Chlorophyll $b$ concentration was unaffected by the shade net treatments. There was positive correlation between chlorophyll $a$ and $b\left(r^{2}=0.948\right)$, while there were no relationships between chlorophyll index with either chlorophyll $a$ or $b$. The chlorophyll $a / b$ ratio ranged from 2.28 (for plants under the black and red nets) and 2.35 (unshaded plants) and was unaffected by shade net treatments.

Leaf CUPRAC values were highest in the red net treatment and unshaded treatment, while lowest under the black and white nets. TEAC values were highest in the red net treatment and lowest in the black net. Total phenols and flavonoids were highest in the red net treatment and in unshaded conditions. Total phenols were reduced in the black and white net treatments.

Leaves contain a diverse group of bioactive secondary plant products that perform diverse functions, including a regulatory effect on other plants, microorganisms, or animals (Larcher, 1995). The concentration and composition of secondary compounds may change in response to environmental conditions. Pigments including Chl $a$, Chl $b$, and carotenoids are involved in photosynthesis and indicate nutritional status. Shaded leaves typically have higher chlorophyll (Chl $a$ and $b$ ) concentrations than unshaded leaves. Leaf chlorophyll concentration increases to maximize photosynthesis under light-limiting conditions (Björkman, 1981). Pepper leaves under black and blue shade nets were found to have higher chlorophyll concentrations compared with leaves under red, pearl, and white nets and unshaded control (Ilic et al., 2017).

In higher plants, Chl $a$ is more important for photosynthesis than $\mathrm{Chl} b$. In the present study, the chlorophyll $a / b$ ratio was unaffected by the shade net treatments. The chlorophyll $a / b$ ratio typically decreases with solar radiation, from a ratio of 3.2 to 4 in sunexposed leaves, to a ratio of 2.5 to 2.9 in shade leaves (Lichtenthaler, 1987).

There is limited information on how shade nets modify light quality and how these modifications influence leaf chemical composition and other plant responses (Kotilainen et al., 2018). Carotenoids protect the chlorophyll molecules from photooxidation under excessive solar radiation. In this study, however, carotenoid concentration was reduced under unshaded conditions, suggesting that photooxidation was minimal under unshaded conditions. In tea plant (Camelia sinensis L.), Chl $a$ and $b$ and carotenoids increased with increasing nitrogen fertilization rate (Wang et al., 2019). The decreased concentration of Chl $a$ under shade nets is consistent with other reports indicating that plants increase chlorophyll concentration to maximize photosynthesis under light-limiting conditions (Björkman, 1981; Larcher, 1995). In the medicinal plant Van Haldi (Hedychium spicatum), phenolics concentrations and antioxidant activities in the rhizomes varied with growth stage and time of the year (Rawat et al., 2014).

In conclusion, compared with unshaded conditions, shade nets resulted in improved bell pepper plant growth and leaf gas exchange. These responses were due primarily to the reduced leaf and root zone temperatures under shaded conditions, regardless of the color of shade net. The differences in plant growth and function due to color of shade net were inconsistent or minor for most plant variables.

\section{Literature Cited}

Aguirreolea, J., J. Irigoyen, M. Sanchezdiaz, and J. Salaverri. 1995. Physiological alterations in pepper during wilt induced by Phytophthora capsici and soil water deficit. Plant Pathol. 44:587-596.

Aied, K.Y., Z. Wahab, R.H. Kamaruddin, and A.R. Shaari. 2017. Growth response of eggplant (Solanum melongena L.) to shading and cultivation inside a greenhouse in a tropical region. Intl. J. Sci. Res. 8:89-101.

Alarcon, J.J., M.F. Ortuno, E. Nicolas, A. Navarro, and A. Torrecillas. 2006. Improving water-use efficiency of young lemon trees by shading with aluminised-plastic nets. Agr. Water Manage. 82:387-398.

Arthurs, S.P., R.H. Stamps, and F.F. Giglia. 2013. Environmental modification inside photoselective shadehouses. HortScience 48:975-979.

Barros, L., P. Baptista, and I.C.F.R. Ferreira. 2007. Effect of Lactarius piperatus fruiting body maturity stage on antioxidant activity measured by several biochemical assays. Food Chem. Toxicol. 45:1731-1737.

Björkman, O. 1981. Response to different quantum flux densities, p. 57-107. In: O.L. Lange, P.S. Nobel, C.B. Osmond, and H. Ziegler (eds.). Physiological Plant Ecology. Responses to the Physical Environment. Springer-Verlag, Berlin.

Boyhan, G., J. Díaz-Pérez, C. Riner, R. Hill, and D. Thigpen. 2008. Evaluation of bell pepper and tomato varieties with and without shade. HortScience 43:1256.

Castro-Concha, L.A., J. Tuyub-Che, A. Moo-Mukul, F.A. Vazquez-Flota, and M.L. Miranda-Ham. 2014. Antioxidant capacity and total phenolic content in fruit tissues from accessions of Capsicum chinense Jacq. (Habanero pepper) at different stages of ripening. Sci. World J. 2014:809073.

Díaz-Pérez, J.C. 2010. Bell pepper (Capsicum annum L.) grown on plastic film mulches: Effects on crop microenvironment, physiological attributes, and fruit yield. HortScience 45:1196-1204.

Díaz-Pérez, J.C. 2013. Bell pepper (Capsicum annum L.) crop as affected by shade level: Microenvironment, plant growth, leaf gas exchange, and leaf mineral nutrient concentration. HortScience 48:175-182.

Díaz-Pérez, J.C. 2014. Bell pepper (Capsicum annum L.) crop as affected by shade level: Fruit yield, quality, postharvest attributes, and incidence of Phytophthora blight (caused by Phytophthora capsici Leon.). HortScience 49:891-900.
El-Aidy, F., M. El-Afry, and F. Ibraheim. 1993. Effect of shade and fertilizer levels and their interaction on fruit yield of sweet pepper. Acta Agron. Hung. 42:59-67.

Elad, Y., Y. Messika, M. Brand, D.R. David, and A. Sztejnberg. 2007. Effect of colored shade nets on pepper powdery mildew (Leveillula taurica). Phytoparasitica 35:285-299.

Fallik, E. 2009. Can colored shade nets maintain sweet pepper quality during storage and marketing? Acta Hort. 830:37-44.

Ilic, Z.S., L. Milenkovic, L. Stanojevic, D. Cvetkovic, and E. Fallik. 2012. Effects of the modification of light intensity by color shade nets on yield and quality of tomato fruits. Scientia Hort. 139:90-95.

Ilic, Z.S., L. Milenkovic, L. Sunic, S. Barac, J. Mastilovic, Z. Kevresan, and E. Fallik. 2017. Effect of shading by coloured nets on yield and fruit quality of sweet pepper. ZemdirbysteAgriculture 104:53-62.

Jones, H.G. 1992. Plants and microclimate. Cambridge University Press, Cambridge.

Kittas, C., N. Katsoulas, N. Rigakis, T. Bartzanas, and E. Kitta. 2012. Effects on microclimate, crop production and quality of a tomato crop grown under shade nets. J. Hort. Sci. Biotechnol. 87:7-12.

Kotilainen, T., T.M. Robson, and R. Hernández. 2018. Light quality characterization under climate screens and shade nets for controlledenvironment agriculture. PLoS One 13:e0199628.

Larcher, W. 1995. Physiological plant ecology. Ecophysiological and stress physiology of functional groups. Springer, Berlin.

LI-COR. 2003. Using the LI-6400. Portable Photosynthesis System. Book 5. Leaf Chamber Fluorometer. LI-COR Biosciences, Inc., Lincoln, NE.

Lichtenthaler, H.K. 1987. Chlorophylls and carotenoids-Pigments of photosynthetic membranes. Methods Enzymol. 148:350-382.

Mahmood, A., Y.G. Hu, J. Tanny, and E.A. Asante. 2018. Effects of shading and insect-proof screens on crop microclimate and production: A review of recent advances. Scientia Hort. 241:241-251.

Ombódi, A., Z. Pék, P. Szuvandzsiev, Z. Tóthné Taskovics, A. Kóházi-Kis, A. Kovács, H. Ledóné Darázsi, and L. Helyes. 2015. Effects of external coloured shade nets on sweet peppers cultivated in walk-in plastic tunnels. Not. Bot. Horti Agrobot. Cluj-Napoca 43:398403.

Oren-Shamir, M., E.E. Gussakovsky, E. Shpiegel, A. Nissim-Levi, K. Ratner, R. Ovadia, Y.E. Giller, and Y. Shahak. 2001. Coloured shade nets can improve the yield and quality of green decorative branches of Pittosporum variegatum. J. Hort. Sci. Biotechnol. 76:353-361.

Rawat, S., I.D. Bhatt, R.S. Rawal, and S.K. Nandi. 2014. Effect of developmental stage on total phenolics composition and antioxidant activities in Hedychium spicatum Buch.-Ham. ex. D. Don. J. Hort. Sci. Biotechnol. 89:557-563.

Reinhart, K.O., A.A. Royo, S.A. Kageyama, and K. Clay. 2010. Canopy gaps decrease microbial densities and disease risk for a shade-intolerant tree species. Acta Oecol. Intl. J. Ecol. 36:530536.

Roberts, B.W. and J.A. Anderson. 1994. Canopy shade and soil mulch affect yield and solar injury of bell pepper. HortScience 29:258-260.

Russo, V.M. 1993. Shading of tomato plants inconsistently affects fruit yield. HortScience 28:1133. 
Rylski, I. and M. Spigelman. 1986. Effect of shading on plant development, yield and fruit quality of sweet pepper grown under conditions of high temperature and radiation. Scientia Hort. 29:3135.

Shahak, Y. 2008. Photo-selective netting for improved performance of horticultural crops. A review of ornamental and vegetable studies carried out in Israel. Acta Hort. 770:161-168.
Singleton, V.L., R. Orthofer, and R.M. LamuelaRaventos. 1999. Analysis of total phenols and other oxidation substrates and antioxidants by means of Folin-Ciocalteu reagent. Methods Enzymol. 299:152-178.

Smith, H. 2000. Phytochromes and light signal perception by plants-An emerging synthesis. Nature 407:585-591.

Stamps, R.H. 2009. Use of colored shade netting in horticulture. HortScience 44:239-241.
Taylor, M.D. and S.J. Locascio. 2004. Blossom-end rot: A calcium deficiency. J. Plant Nutr. 27:123139.

Wang, Y.J., X. Hu, G. Jin, Z.W. Hou, J.M. Ning, and Z.Z. Zhang. 2019. Rapid prediction of chlorophylls and carotenoids content in tea leaves under different levels of nitrogen application based on hyperspectral imaging. J. Sci. Food Agr. 99:1997-2004. 